\title{
The Pedestrianisation and Its Relation with Enhancing Walkability in Urban Spaces MA. NAJMALDIN HUSSEIN ${ }^{1}$ \\ ${ }^{1}$ Department of Architecture, Faculty of Architecture, Eastern Mediterranean University, Turkey E mail: najmaldin.hussein@gmail.com
}

\begin{tabular}{l} 
A R T I C L E I N F O: \\
\hline Article history: \\
Received 20 June 2017 \\
Accepted 20 August 2017 \\
Available online 25 September \\
2017 \\
\hline Keywords: \\
Walkability; \\
Pedestrianisation; \\
Safety; \\
Quality of urban \\
environment.
\end{tabular}

This work is licensed under a Creative Commons Attribution NonCommercial - NoDerivs 4.0. "CC-BY-NC-ND"

\begin{abstract}
A B S T R A C T
The study aimed to answer the question of how pedestrianisation can influence walkability to increasing physical activity vitality and livability of urban spaces. Therefore, after the theoretical understanding of the framework of the research, the study will focus on experimental research on the Salamis rode of Famagusta to assess the problems of walkability in the street to propose a sustainable and human friendly solution for this area. The main aim of the research is to find what is the interrelation between pedestrianisation in public urban spaces and walkability? Therefore, it concludes that walkability as a part of pedestrianisation scheme will lead to increase the quality of the urban environment by increasing safety and organization in urban infra-instructors.
\end{abstract}

JOURNAL OF CONTEMPORARY URBAN AFFAIRS (2018) 2(1), 102-112.

https://doi.org/10.25034/ijcua.2018.3666

\section{Introduction}

Due to increasing the vehicular traffic in the contemporary urban spaces, it creates lots of problems for its users. These problems effects on the ability of walking in space by increasing noise and decreasing safety in the environment. As a result the vitality and livability of urban spaces will decrease and people will also lose sense place which is the result of unsustainability in spaces. This research after a theoretical understanding of the pedestrianisation and its relation with walkability in urban spaces will introduce a model of assessment in public urban spaces. Consequently, the study will apply the model in the context of Famagusta. The output of the study will also be useful for urban designer and architectures to understating the problems which lack of walkability might appeared for its users the fore it will propose long term and short term proposal to increase walkability in urban spaces and especially in Salamis Road of Famagusta.

\section{Literature Review}

2.1. The Role of Pedestrian Walkable Streets in Urban Sustainable Development

Appleyard (1981) in his book "livable streets" claims that streets should have social functions as well as facility functions. Gehl (1987) discusses about the appropriate planning of streets for pedestrian by highlighting social activities. Simpson (1988) believes that developing old city centres might increase walkability and the quality of urban spaces. in this regard, Bahreini (1998, 292) states that, Street related issues are selfgoverning subjects in new urbanism, as well as safety, social aspects, attraction, pedestrians, mixed land uses. Previously, cities were recognised by its tall and huge building and construction, but nowadays pedestrian streets

*Corresponding Author:

Department of Architecture, Eastern Mediterranean University, Famagusta, Mersin 10, Turkey

E-mail address: najmaldin.hussein@gmail.com 
are the main streets to identify the identity and characteristic of a city.

Compensations of pedestrianized streets and alleys presents the flexibility, exhilaration, dynamism comfort, breezing, clarity, connection, not using unsustainable energy resources, reliability. Table 1 illustrates the role of pedestrianisation in increasing the quality of urban environment.

Table1. The role of pedestrianisation in increasing the quality of urban environment.

\begin{tabular}{|c|c|c|}
\hline Environmental importance & Definition & Role \\
\hline $\begin{array}{l}\text { Preventing pollutions and } \\
\text { activate people }\end{array}$ & $\begin{array}{l}\text { Most contemporary cities are automobile oriented } \\
\text { which lead to less activities and high } \\
\text { risk(Ahmadi,Habib,2007). } \\
\text { (Montgomery, et al,2008) }\end{array}$ & $\begin{array}{l}\text { The role of } \\
\text { physical and } \\
\text { mental health }\end{array}$ \\
\hline $\begin{array}{l}\text { Increasing public control on } \\
\text { environment and preventing } \\
\text { harms }\end{array}$ & $\begin{array}{l}\text { Pedestrian streets are beds of social interactions which } \\
\text { increase public control and lower crime and } \\
\text { disorders(Ahmadi,Habib,2007). } \\
\text { (Montgomery, et al,2008) }\end{array}$ & Social role \\
\hline $\begin{array}{l}\text { Decreasing fuel consumption, } \\
\text { traffic, etc }\end{array}$ & $\begin{array}{l}\text { Pedestrian streets affect economic issues seriously and } \\
\text { cause citizens' interaction with financ ial landuses. }\end{array}$ & Economic role \\
\hline $\begin{array}{l}\text { Decreasing unsusta inable } \\
\text { energy consumption and } \mathrm{CO}_{2} \\
\text { production, increasing } \\
\text { greeneries }\end{array}$ & $\begin{array}{l}25 \% \text { of pollutions rise from automobiles while } \\
\text { transportation system energy consumption is about } \\
12 \% \text { in different countries(Ahmadi,Habib,2007). } \\
\text { (Montgomery, et al,2008) }\end{array}$ & Ecologic role \\
\hline $\begin{array}{lr}\text { Comfort, } & \text { vitality, } \\
\text { exhilaration, linked } & \text { natural } \\
\text { and human } & \text { made } \\
\text { environments } & \end{array}$ & $\begin{array}{l}\text { Pedestrian spheres pave the ways for social } \\
\text { interactions which create memories. They strengthens } \\
\text { people' image of the city(Ahmadi,Habib,2007). } \\
\text { (Montgomery, et al,2008) }\end{array}$ & Perceptual role \\
\hline $\begin{array}{l}\text { Decreasing pollutants, } \\
\text { conserving land, optimizing } \\
\text { transportation system }\end{array}$ & $\begin{array}{l}\text { Using non-motorized vehicles affects quality of life } \\
\text { severely(Ahmadi,Habib,2007). } \\
\text { (Montgomery, et al,2008) }\end{array}$ & $\begin{array}{l}\text { Non-motor ized } \\
\text { vehic les }\end{array}$ \\
\hline $\begin{array}{l}\text { Compatibility with ecology, } \\
\text { being inclined to walking, } \\
\text { reduce the use of cars }\end{array}$ & $\begin{array}{l}\text { Walking is healthiest and cheapest way of moving in } \\
\text { cities, in harmony with the environment(Montgomery, } \\
\text { et al,2008). }\end{array}$ & $\begin{array}{l}\text { Proper spaces } \\
\text { for walking }\end{array}$ \\
\hline $\begin{array}{l}\text { Using clean energies, meeting } \\
\text { needs by walking, decreasing } \\
\text { trips and contamination }\end{array}$ & $\begin{array}{l}\text { Vehicles need to be environment-friendly, have low } \\
\text { energy consumption with no sound pollution and be } \\
\text { safe for the users. Optimized management is } \\
\text { necessary for each city, designed for human priorities. }\end{array}$ & $\begin{array}{l}\text { Trip } \\
\text { management } \\
\text { using } \\
\text { pedestrainizatio } \\
\text { n }\end{array}$ \\
\hline
\end{tabular}

\subsection{Walkability and Its Interrelation between Quality of Urban Environment}

Gehl (1996) defined social activity while two people are together in one specific place. So the purpose of being with each other might vary. The meeting is somehow represent as a seed for inclusive forms of social activities. This construction is important in relate to pedestrianisation. Even if the physical component and its organization does not have a direct effect on the quality of urban environment and intensity. By respecting to the outcomes of pedestrianisation can affect the possibilities for meeting, seeing, and hearing people.

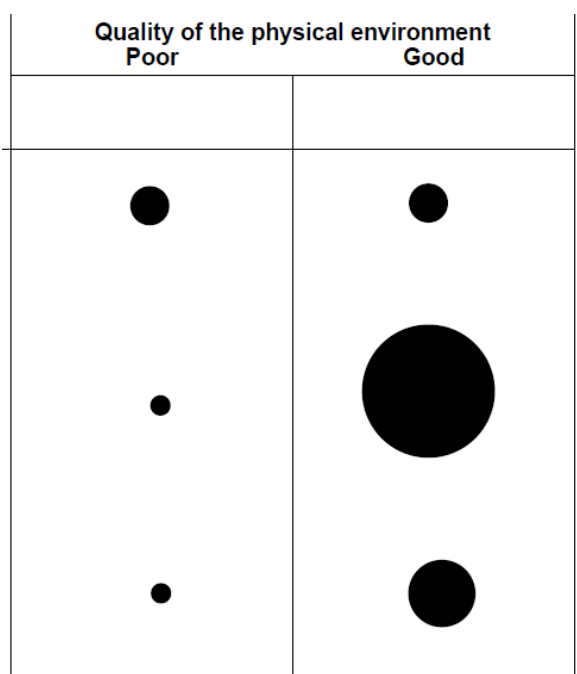

Figure 1. The interrelation between walkability and quality if physical environment based on Gehl, 1996. 
In this regard it is hypothesized in this research that the quality of public urban spaces has direct relation with walkability in urban spaces. It means that in order to increase the amount of users in urban spaces. The environment should fulfill people's requirements by applying the principals of pedestrianisation.

\section{Pedestrianisation}

Pedestrianisation is a process of closing streets to vehicle traffic. It might be during certain hours or permanently. - Pedestrianisation improves safety and accessibility for pedestrians. From the other hand it brings larger environmental, economic and social benefits for its cities. It develops public health by preparing a chances of physical activity over traffic safety and active transport. Pedestrianisation by decreasing traffic and the cars on the road helps to decrease greenhouse gas. Therefore it mitigate global climate change. Lastly, pedestrianisation help to fosters businesses in small scale and economic growth by considering cultural exchange and tourism. By combination and implementation of pedestrianisation in context of urban spaces it leads to generate urban spaces that are sustainable and liveable by refining quality of life for residents of urban spaces.

\subsection{Types of Pedestrianisation}

There are different type and methods on the pedestrianisation of urban spaces regarding to the problem of the context and aim of the projects in urban spaces the methods of applying one of them might be different in different contexts:

A-Full time pedestrian streets

In this method of design of streets for urban spaces the main aim in to increase and highlight the social activity and livability of public urban spaces in sum part of the city. Therefore, the method of design is based on abandoning the vehicular traffic inside of the streets. It means that the streets will just belong to the pedestrians and only emergency service vehicles will be allow to enter to Full time pedestrian streets.

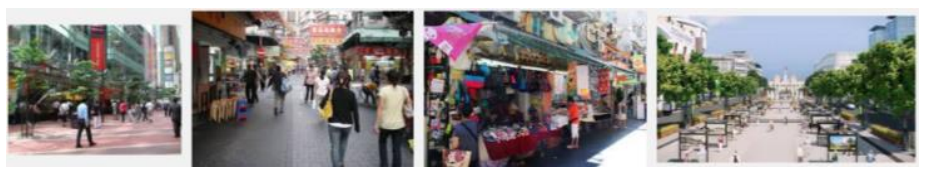

Figure 2. Full time pedestrian streets.

\section{$B$ - Part-time Pedestrian Streets}

There are some pedestrian streets which are allow for vehicles to come streets for one specific time. In this kind of streets there is no parking spaces for cars along the streets. But loading bays are obtainable.
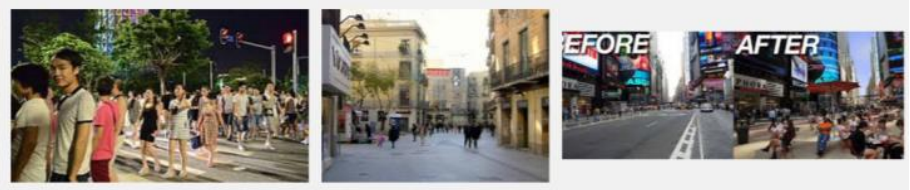

Figure 3. Examples of Part-time Pedestrian Streets.

\section{C- Traffic Calming Streets}

The last type of streets regarding to pedestrianisation designed to decrease the speed and dominance of road vehicles. In this kind of streets there are no limits for access of motor vehicles. But footpaths for pedestrians extended and parking spaces are reduced as much as possible. In these streets they are using different methods and technique to slow down the speed of cars by using diverse colors and road textures to tell the drivers that they are in traffic calming streets 

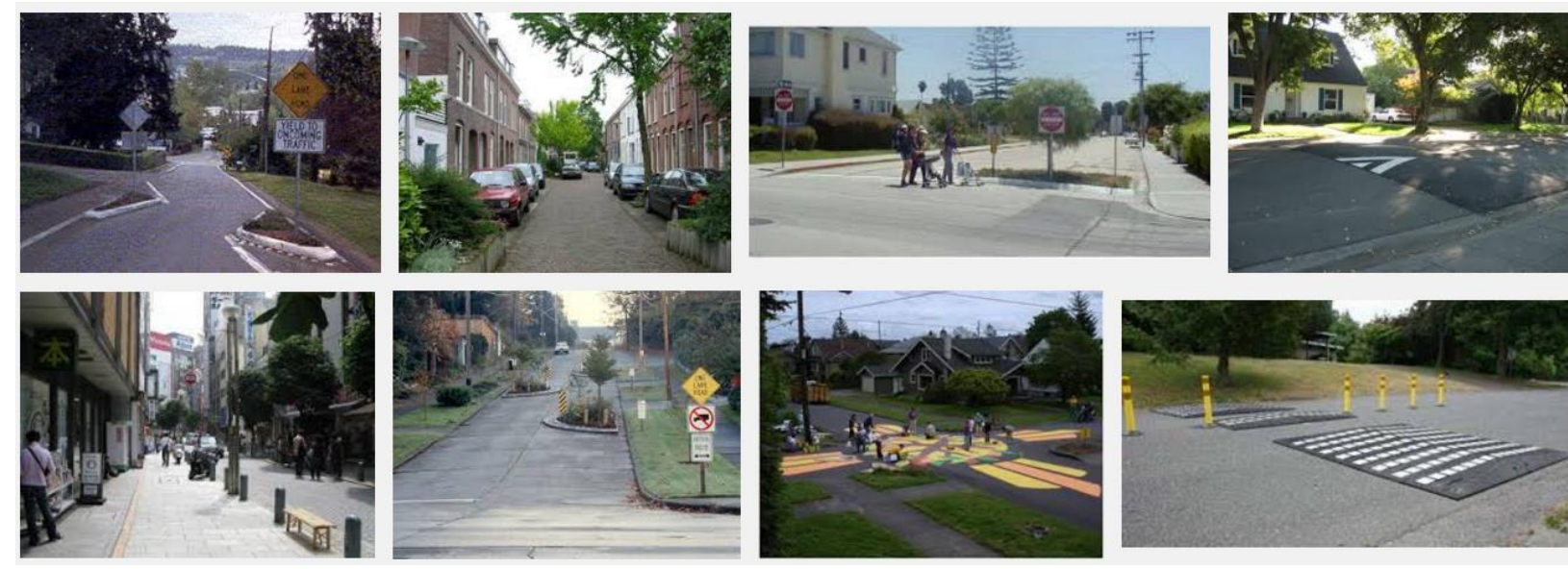

Figure 4. Examples of Traffic Calming Streets.

\section{Why Pedestrianisation Is Required?}

There might be a various reasons for applying pedestrianisation principals in the context. As a result of pedestrianisation pedestrian's safety and mobility will increase. Pedestrianisation also has environmental effects by helping to reduce noise and pollution by restricting access of vehicles. It also increase walkability by increasing the quality of urban environment. As a result of pedestrianisation schemes in the urban context safety and social activity might increase.as a result, pedestrianisation might create an enjoyable atmosphere that people can involve in it from diverse cultural, social contexts. It also effects on the quality of tourism. The study also revealed that pedestrianisation can lead to economical growing of a context.

Pedestrianisation is related to the pedestrian facilities and in order to successfully design of it. The designer should consider that human needs are vary from different culture and background. And the successful design should encompass all of the requirements.

Considering Maslow's hierarchy of needs the study developed a framework (figure5) which are suitable to apply and interoperate in pedestrianisation programs. Therefore the program of pedestrianisation starts from the basic physical requirements in urban spaces such as the basic physical and structural requirements of urban spaces. Then the pedestrianisation should support and increase safety by decreasing vehicular traffic and crime prevention in pubic urban spaces. After the fuilfiling the physical needs in the pedestrianisation schemes the other needs which the designer should focus is socialization needs. It means that in the design should be in a way that people easily interacts with each other and also it should prepare a chance of self-actualization.

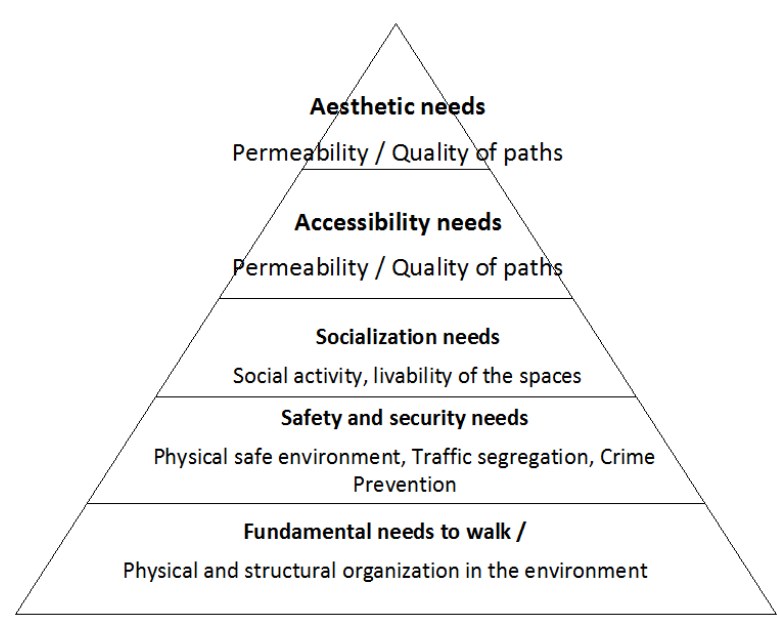

Figure 5. The hierarchy of human needs regarding to walkability (Developed by Author).

Accordingly, Sobri and Sulaiman (2004) believes that participation of a large community with the body of local institution can be able to create more pedestrian friendly, responsive environment with high quality therefore it reveals the significance of pedestrian activities in environmental configuration. In this regard, Qualitative assessment of Pedestrian Flow are possible by A) Ability to walk B) Freedom to pass. C) Adjournment at signalized intersections. D) Ability to cross a stream of pedestrians. E) Ability to move without conflicts. F) Freedom to select a desired speeds. As a result, the study proposed to categorize the compensations of pedestrianisation in three main category:

\subsection{Environmental Impacts of Pedestrianisation}

Considering the effects of pedestrianisation on physical objective environment it would be possible to mention that decrease noise and air pollution by reducing the number of vehicles around the pedestrianized area. Pedestrianisation by preparing the opportunity to 
walk as one of the modes of transportation without any need to oil, so pedestrianisation can reduce fuel consumption as well.

Pedestrianisation also prepares opportunities for additional planting areas and improving landscaping and street furniture and as a result of pedestrianisation it's possible to conclude that it helps to create a better environment and beautify the local streets.

\subsection{Economic Impacts Pedestrianisation}

Pedestrianisation by decreasing heavy motor vehicle traffic leads to large economic saving in term of air pollution and medical expenses due to the healthy environment that urban environment might prepares for its environment. With less car traffic and fewer pollution once pedestrianisation, there are often a discount in prices incurred. Consequently, the less air pollution will lead to the less interrelated medical costs. From the other hand by increasing the number of people which come to use of the spaces due to the opportunity which pedestrianisation prepares by walkability will increase retails income in that area. From the other hand the role of rental income and occupancy rate will also increase. In pedestrianized spaces people will welcome food retails and coffee shops. From the other hand the pedestrianized streets are also welcome to tourists to come and enjoy the quality and potential that the environment might propose for its users.

\subsection{Social Impacts of Pedestrianisation}

The application of the rules and principals of pedestrianisation might have a number of social impacts. Firstly it increase walkability. As a result of walkability people will have the opportunity of social interaction with each other it will help them to be familiar with people and culture around them. "Pedestrianized streets in many cities also served as cultural and entertainment plazas where people meet and greet not only during ordinary days but also during holidays and festive seasons as well. Free of vehicle Traffic Street, in many cases by landscaping, street furniture and sidewalks, help to create a comfortable environment for people to engage them in various social activities." (Iranmanesh, 2008) Pedestrianisation can also by increasing separation vehicles from peoples lead to the safety in urban spaces.

\section{Walkability and its Relation with Pedestrianisation}

Walkability is a quantity of how friendly an area is to walk in that environment (?). Walkability has many economic, health, and environmental and benefits. Factors which effects on walkability contain traffic and road conditions, sidewalks or other pedestrian right-of-ways, building accessibility, and safety, land use patterns and quality of footpaths. Walkability which is one of the strategies of pedestrianisation prepare many community and individual health benefits. As an example the chances for increasing social interaction by increasing the number of friends in social environment. From the other hand, since, more people watching and walking over street it will reduced crime. Consequently, Walkability will lead to increased volunteerism and increased sense of pride. "Walkability has also been found to have many economic benefits, including accessibility, cost savings both to individuals and to the public, increased efficiency of land use, increased liveability, economic benefits from improved public health, and economic development, among others." (Refaat and Kafafy 2014).

Considering the definition of "walkability" in the dictionary of Merriam Webster Which refers to "suitability for walking" it prepares easily walking to different places.in this regard, Abley \& Turner(2011) believes that the environmental configuration can prepare the main role in the creating an suitable status for walking" . Consequently, based on MARC report (1998) "Walkability is the quality of walking conditions and the degree to which the built environment encourages walking by providing pedestrians a safe, comfortable, convenient and appealing travel corridor"

To be able to assess the interrelation between walkability and pedestrianisation it's necessary to mention that walkability is part of strategy for pedestrianisation of the environment. Pedestrianisation strategy needs the concentration of different dimension of urban design from social, economic, environmental and morphological dimension. So it looks a kind of master plan which needs to assess and evaluate the context before applying in the context. From the other hand, according to the definition in previous paragraphs walkability is qualitative assessment of the environments to assess how pedestrianisation is successful in urban environment.in the following figure 4 you may see some successful examples of applying pedestrianisation principals in urban context. 
Pedestrianisation increase the quality of urban

environment.
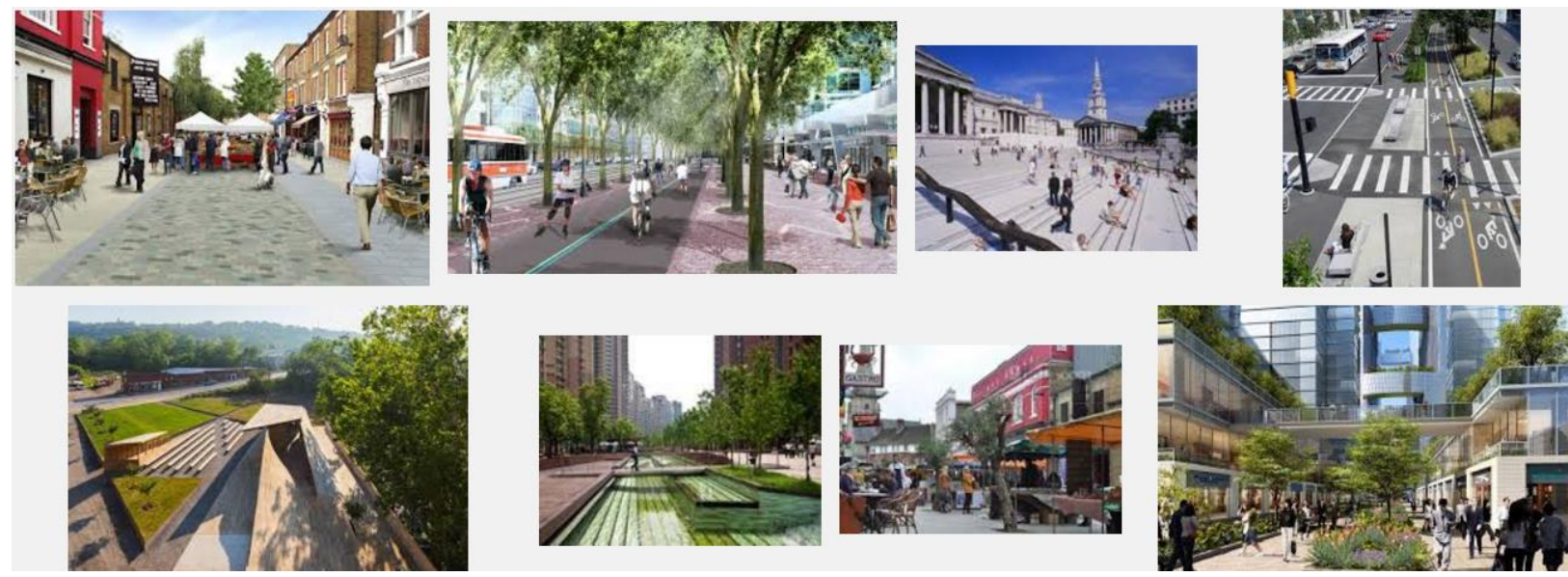

Figure 6. Examples of applying pedestrianisation principals in urban spaces.

\section{Concepts for Improving Walkability:}

The study on NZTA (2009) on the principals of improving the pedestrian environment reveals four main classification in this literature which are highly effects of the applied context. These potentials are A) shared zones and sharing the main street Living streets, pedestrian precincts. Below paragraphs explains these concepts in detail. Understanding the component of each classification will help to comprehend the diverse ways and methods for improving the walkable urban spaces.

\section{Living streets}

The idea of living streets (LS) refers to the fact that Streets must designed with community and living interface. It objectives of LS is to create an increase the quality of life and urban environment by creating a balance between pedestrians and cyclists with cars, residents, businesses. Therefore LS will lead to greater rage of street and community activity.

LS may include:
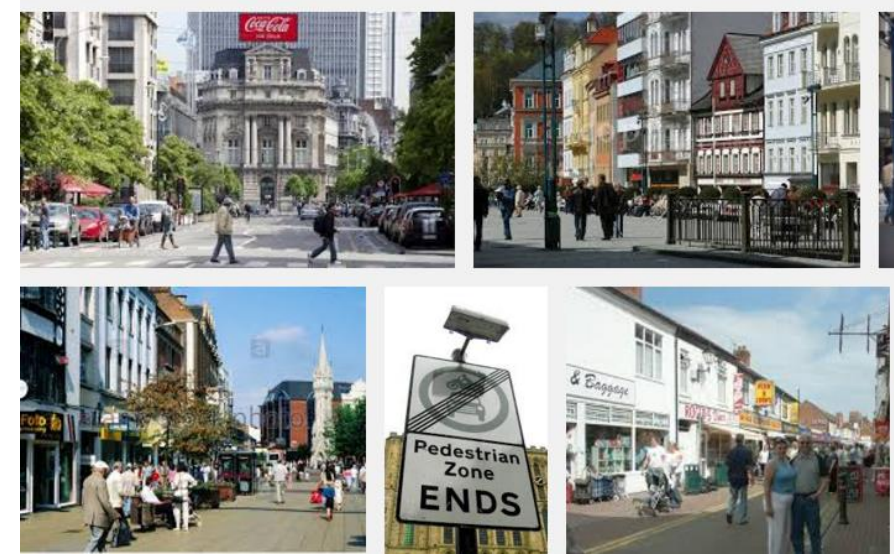

Figure 7. Examples for strategy Pedestrian precincts (PP) streets.
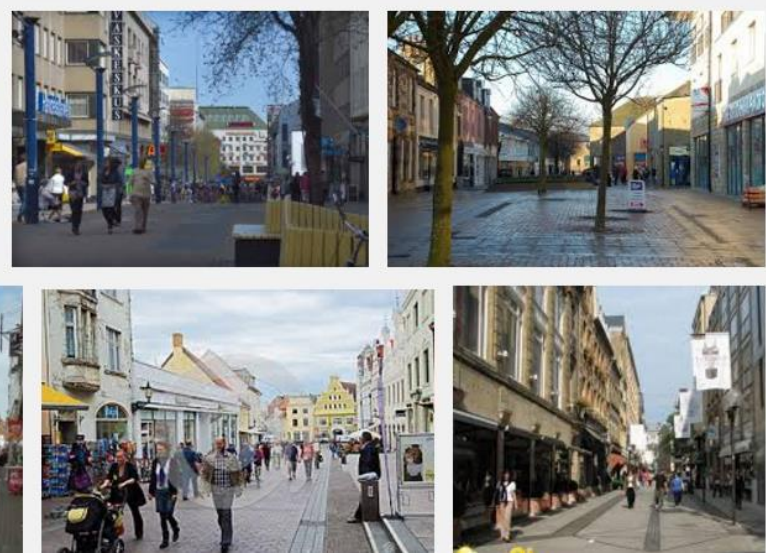

The strategy of PP are most helpful if we had a high number of pedestrian and/or vehicle
A) Designing soft and hard landscape area. B) Methods of Traffic-calming. C) Designing places for social activity which are inclusive for all range of peoples. D) Designing with the purpose of mixed activities. E) Designing public art, and essential requirements of street infra-instructors. F) (ncreasing infrastructures of lightening in the night to . In theory the idea of LS can be applicable to any other streets. Therefore there is always a

Pedestrian precincts (PP)

Approximately all pedestrian places designed in such a way that to limit the access of vehicles to the pedestrianized area. There are four type of PP which are:

A. Using of alleys and lanes.

B. Modified PP which in this case one block is cked for only pedestrian use.

C. cross-streets and several blocks are closed.

D. Plaza 
conflicts, heavy pedestrian activity, retail or mixed development. Therefore, the access should design in such way that to emergency services.

\section{Shared Zones}

Shared zone (SZ) is a method to apply and regenerate Living Street in the streets which entering the vehicles to the area are inevitable.in this regard the will be specific restrictions for vehicels wile enterin shared Zones such as speed limits.
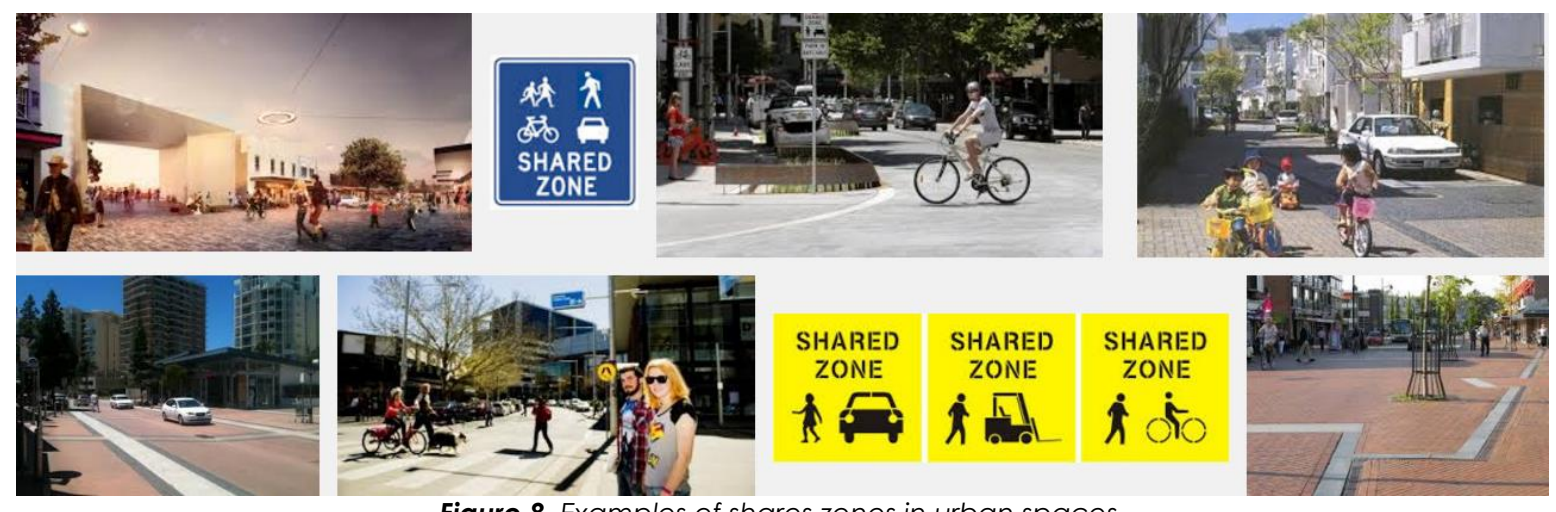

Figure 8. Examples of shares zones in urban spaces.

\section{Sharing the Main Street}

Sharing the main streets refers to the idea of peaceful coexistence of pedestrians and cars next to each other. Therefore the design strategy for main streets by considering the principals of sharing the main streets refers to the Ida of improving quality of street environment and safety for all people (Grant, et all 2005). In this kind of street there are some concern which needs to consider while designing it:

A. Businesses should design in such a way that to increase vitality and livability.

B .preparing a situation for pedestrian for crossing safely.

C-there should be able of possibility for visitors of street to park along the street.
"Shared zones are most suitable for streets and compact areas with a low demand for through traffic movement. Their maximum size is restricted by the need to maintain response times for emergency services and to limit the extent of roadway that must be negotiated at low speeds by motorists accessing their properties." (Gerrard, 2005). Figure 8 illustrates some examples of shares zones in urban spaces.

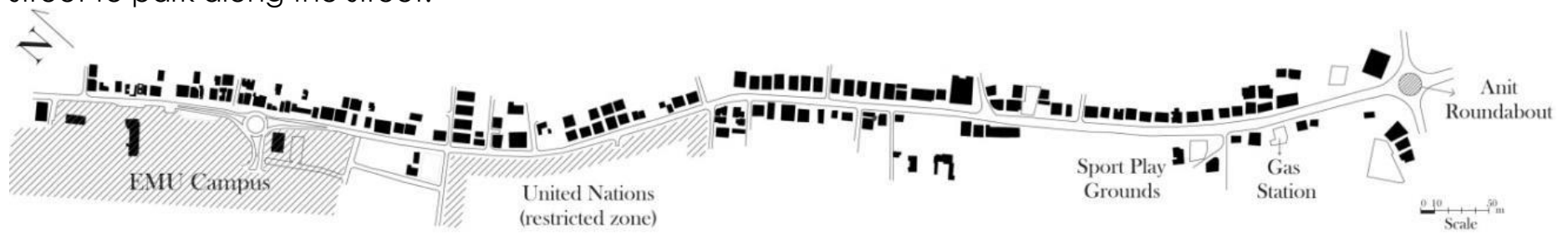

Figure 9. The location of Salamis Street in Famagusta town.

The study realized that the streets and pedestrian has different variety which increase the problem walkways are not in standard size and dimension. D-there should be parking spaces for trucks for loading and unloading.

E- Cyclists and Motorists needs to move safely and slowly.

\section{Case Study}

Salamis rode of Famagusta selected as a case study. Since the area has lots of problems regarding to walkability the strategy pedestrianisation is required to apply in the context. In this regard, experimental research method have been used as a methodology for assessment of the problems regarding to walkability.

In this regard the proportion of street organization 

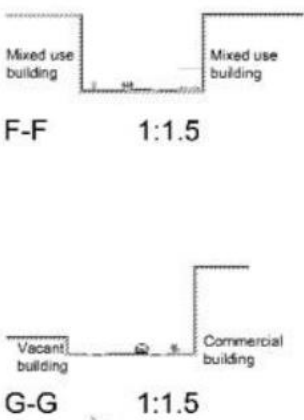
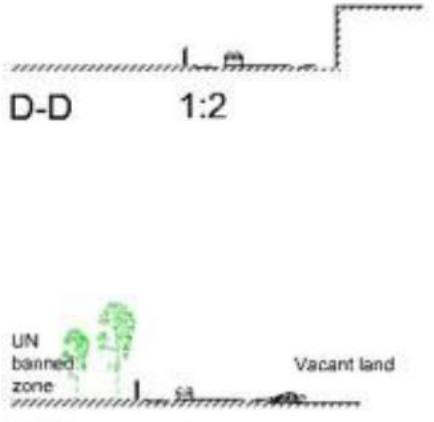

1:1

\section{$E-E$}

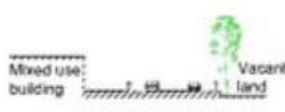

K-K $\quad 1: 3$

Figure 10. Various street proportions in Salamis Road.

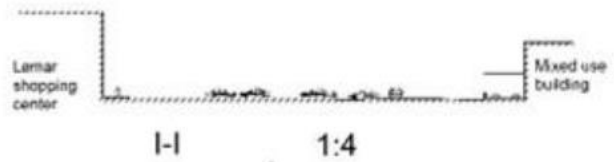

the level and quality of walkability in urban spaces. The questioners distributed in the slalamis rods between the pedestrians. Finally 81 Considering the theretical fraimwork of the research the study investigate major physical problems of Salamis road of Famagusta regarding to walkability. Considering the theoretical framework of the research the study prepare 10 main question which asked from the residence ans passenger of salamis road to assess

Table 2. Problems regarding to Walkability in Salamis Road.

\begin{tabular}{|l|l|}
\hline $\mathbf{1}$ & Low permeability. \\
\hline $\mathbf{2}$ & Having not a proper design. \\
\hline $\mathbf{3}$ & An undefined roundabout. \\
\hline $\mathbf{4}$ & $\begin{array}{l}\text { Existence of many vacant } \\
\text { lands. }\end{array}$ \\
\hline $\mathbf{5}$ & $\begin{array}{l}\text { Existence of abandoned } \\
\text { buildings. }\end{array}$ \\
\hline $\mathbf{6}$ & Low street enclosure. \\
\hline $\mathbf{7}$ & $\begin{array}{l}\text { Existence of banned areas of } \\
\text { UN. }\end{array}$ \\
\hline $\mathbf{8}$ & $\begin{array}{l}\text { Existence of many poor } \\
\text { architecture buildings. }\end{array}$ \\
\hline $\mathbf{9}$ & $\begin{array}{l}\text { Narrow sidewalks with } \\
\text { decayed pavement } \\
\text { materials. }\end{array}$ \\
\hline $\mathbf{1 0}$ & Lack of parking spaces. \\
\hline
\end{tabular}

questioners collected from them. The average/mean of each question revealed in Table 2.

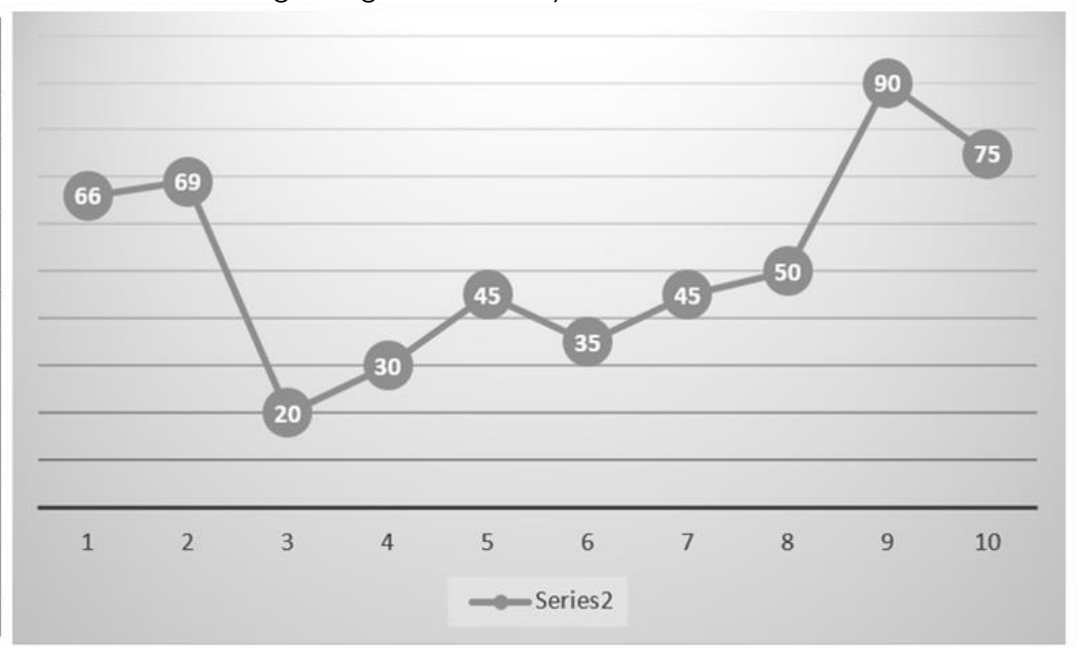

\section{Discussion}

Literature of pedestrianisation in public urban spaces revealed that increasing the quality of public urban spaces by respecting to the Maslow's hierarch of needs will leads to increase the walkability of the urban spaces. Pedestrianisation also can be as a good methodology to increase walkability in the context. Salamis road is a good example to show that the lack of principals of pedestrianisation might lead to catastrophic in the cities. The experimental study have been conducted to Salamis road of Famagusta by 10 questions regarding to the problems of walkability. 90 percent of the respondents believes that the major problem in the street is damaged pavement materials and narrow sidewalk. Based on the analysis of the question, they believes that the street does not have a proper design. The idea refers to the fact that the city doesn't have any specific master plan. Lack of public spaces is also another problems which creates lots of problems for its users by decreasing safety.

Existence of UN area are and the lack of Enclosure in street environment leads also to the main problems of walkability for its users.

\subsection{Difficulties in Creating Walkable Streets in Salamis Streets}

As a discussion the study revealed the main Difficulties in Appling the principals of pedestrianisation in the Salamis Road in Famagusta. 
Table 3. Difficulties in creating walkable streets in Tehran and proposed solutions.

\begin{tabular}{|l|l|}
\hline \multicolumn{1}{|c|}{ Difficulties } & \multicolumn{1}{c|}{ Solutions } \\
\hline $\begin{array}{l}\text { Non-awareness of citizens; duty of people } \\
\text { and the local government regarding the } \\
\text { advantages of walking and walking streets }\end{array}$ & $\begin{array}{l}\text { Defining the importance and characteristics of } \\
\text { walkable streets in the domain of urban } \\
\text { livability and economic growth }\end{array}$ \\
\hline $\begin{array}{l}\text { Famagusta's citizens overuse private cars } \\
\text { for intercity trips }\end{array}$ & $\begin{array}{l}\text { Development of public transportation and } \\
\text { providing for necessary facilities and financing }\end{array}$ \\
\hline Unsuitable location of walkable streets & $\begin{array}{l}\text { Establishing a technical committee for walking } \\
\text { streets, composed of beneficiary organizations } \\
\text { for locating, approving plans and supervision } \\
\text { of their implementation }\end{array}$ \\
\hline Some incorrect beliefs in a few people & $\begin{array}{l}\text { Defining public advantages resulting from the } \\
\text { creation of car-free zones, especially as a } \\
\text { Means for increasing social ties. }\end{array}$ \\
\hline Creation of inharmonic land uses & $\begin{array}{l}\text { Paying attention to areas with high potential in } \\
\text { non-central new neighborhoods }\end{array}$ \\
\hline $\begin{array}{l}\text { Partial and one-dimensional attitude in } \\
\text { definition of pedestrian-oriented projects. }\end{array}$ & $\begin{array}{l}\text { Creation of consensus among experts and } \\
\text { influencing organizations via proposed } \\
\text { technical committee }\end{array}$ \\
\hline $\begin{array}{l}\text { Little experience in creating pedestrian } \\
\text { streets in Famagusta Municipalities. }\end{array}$ & $\begin{array}{l}\text { Increasing the number of pedestrian-oriented } \\
\text { projects to be implemented at different scales }\end{array}$ \\
\hline
\end{tabular}

Regarding to these problems in the city of Famagusta which completely suffering from lack of pedestrianized streets. It seems that there should be some polices for increasing quality of urban pedestrian streets.

Table 4. Polices for increasing quality of urban pedestrian streets.

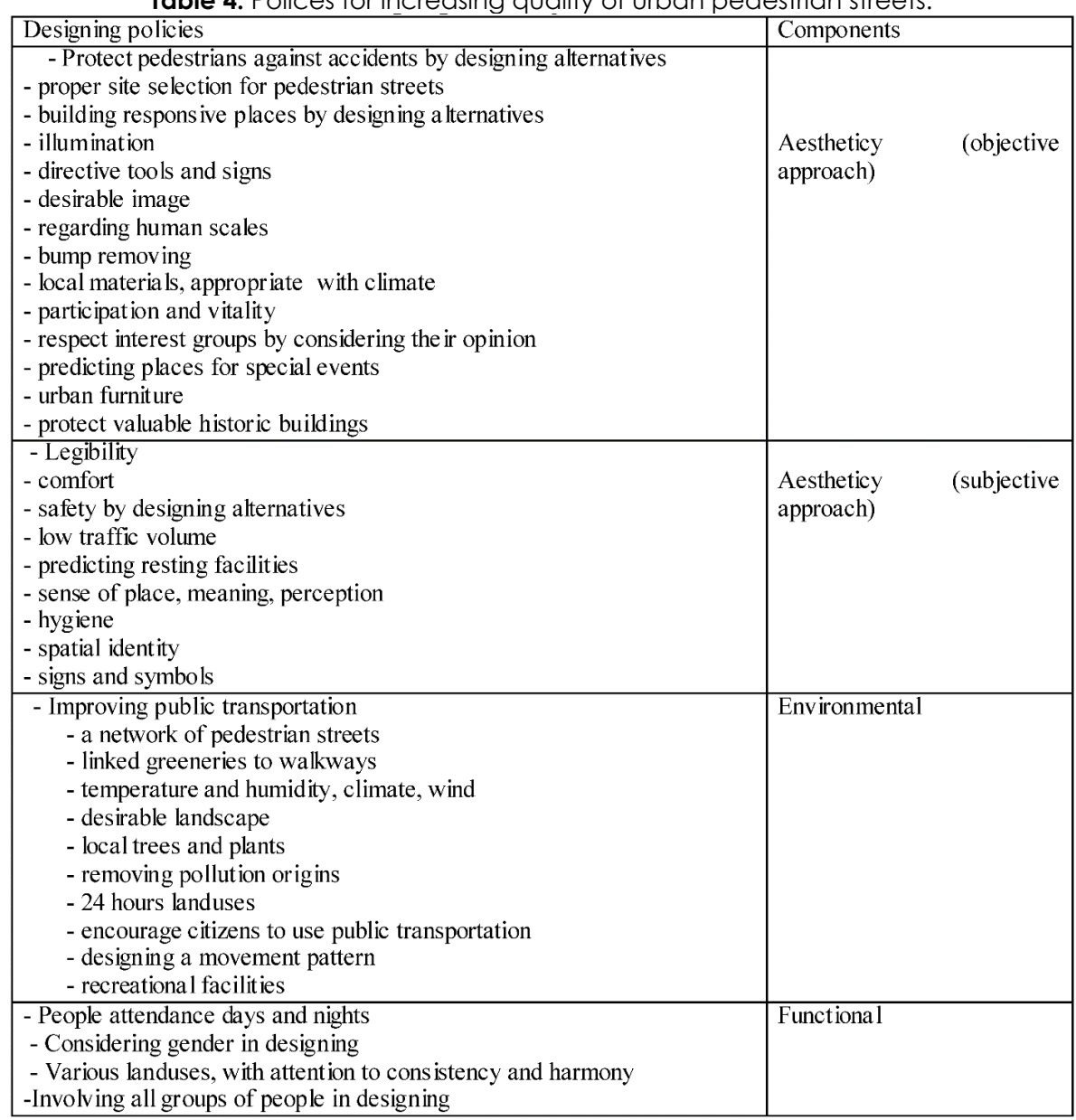

Thesis policies theoretically developed. In order to apply in the context there should also be a methodological proposal to apply in the context. The following table prepare a comprehensive context for architecture and urban designer to 
use all of them to apply in the context. The indicators and proposals developed based on the literature review.

Table 5. Methodological proposal of designing pedestrian urban spaces with the focus of salamis road.

\begin{tabular}{|c|c|c|c|}
\hline \multicolumn{3}{|l|}{ Inclusive dimensions } & $\begin{array}{l}\text { Quality components } \\
\text { of sustainable city } \\
\text { designing }\end{array}$ \\
\hline \multicolumn{2}{|c|}{$\begin{array}{l}\text { Social interactions, survival, respect, celebrating the city, } \\
\text { memories, customs, distinctive spots(Risser,Chaloupka,2010) }\end{array}$} & $\begin{array}{l}\text { Social and } \\
\text { cultural }\end{array}$ & \multirow{4}{*}{$\begin{array}{l}\text { Aestheticy } \\
\text { (subjective approach) }\end{array}$} \\
\hline \multicolumn{2}{|c|}{$\begin{array}{l}\text { Ecological sustainability related to drainage and wastes, air and } \\
\text { sound pollution, traffic and greeneries } \\
\text { Risser,Chaloupka,2010) }\end{array}$} & Environmental & \\
\hline \multicolumn{2}{|c|}{$\begin{array}{l}\text { Net income, life standards, retails, land value } \\
\text { (Risser,Chaloupka,2010) }\end{array}$} & Economic & \\
\hline \multicolumn{2}{|c|}{$\begin{array}{l}\text { Traffic control, directive signs and tools, proper image, bump } \\
\text { removing, up leveled walk ways with streets }\end{array}$} & Physical & \\
\hline \multirow{2}{*}{$\begin{array}{l}\begin{array}{l}\text { Designing features, related to street } \\
\text { pedestrian streets and } \\
\text { (Risser,Chaloupka,2010). }\end{array} \\
\begin{array}{l}\text { Designing features, related to crime, landuses, } \\
\text { attendance, } \\
\text { (Risser,Chaloupka,2010) }\end{array}\end{array}$} & Comfort & \multirow{5}{*}{$\begin{array}{l}\text { Individual } \\
\text { needs }\end{array}$} & \multirow{5}{*}{$\begin{array}{l}\text { Aestheticy } \\
\text { (objective approach) }\end{array}$} \\
\hline & Safety & & \\
\hline $\begin{array}{l}\text { Variety, proximity of landuses, pedestrian streets } \\
\text { network, related } \quad \text { buildings } \\
\text { (Risser,Chaloupka,2010) }\end{array}$ & Access & & \\
\hline $\begin{array}{l}\text { Dynamism, time and responsibility } \\
\text { (Risser,Chaloupka,2010) }\end{array}$ & Feasibility & & \\
\hline $\begin{array}{l}\text { Diversity and complexity, scale, aestheticy, } \\
\text { vitality (Risser,Chaloupka,2010) }\end{array}$ & Desirability & & \\
\hline \multicolumn{3}{|c|}{$\begin{array}{l}\text { Low air and sound pollution, safety, greeneries, slow down the traffic in } \\
\text { neighborhoods(Fruin.2004)(Longo, 2004) }\end{array}$} & \multirow[t]{3}{*}{ Environmental } \\
\hline \multicolumn{3}{|c|}{$\begin{array}{l}\text { Omitting cars from urban spaces and developing walkways (Fruin.2004)(Longo, } \\
\text { 2004) }\end{array}$} & \\
\hline \multicolumn{3}{|c|}{ Traffic management using public transportation (Fruin.2004)(Longo, 2004) } & \\
\hline \multicolumn{3}{|c|}{$\begin{array}{l}\text { Accessible for all groups with any age, gender, ability and color, safety against } \\
\text { accidents, charisma and diversity, various facilities and equipments. }\end{array}$} & Functional \\
\hline
\end{tabular}

\section{Conclusions}

The main aim of pedestrian streets is to design public spaces with high priority for pedestrians. In pedestrianized streets vehicles entrance to the area are abandoned. Therefore designing a pedestrianize street will increase vitality and livability of urban spaces. In the case of Salamis Road which is suffering from lack of walkable public urban spaces should reinforced with basic urban infrainsructurs such as public transportation, parking lots, urban furniture and fixtures should also organized. The pedestrian pathways should also linked and connect with each other in such a way that easily usable for disables as well.

The study conclude that increasing quality of urban spaces and street connectivity and finally applying al the principals of walkability will have direct effect in increasing the walkability of urban spaces.

The outcomes of this paper offers initial indication to highlight the meaning of "Including street connectivity" regarding to walkability of urban spaces. Therefore, the primary elements of 
walkability should support and organize in such a way that to increase safety in urban spaces.

Regarding to the research question the study highlighted the fact that walkability is the result of pedestrianisation program. It means that pedestrianisation considers broad area in urban design from social to economical to find a solution to increase the quality of urban environment. As a result of increasing quality of urban environment regarding to urban infrastructure and furniture and fixtures, walkability in urban spaces will increase.

\section{Acknowledgement}

This research did not receive any specific grant from funding agencies in the public, commercial, or not-for-profit sectors.

\section{References}

Appleyard, Donald. (1981). Livable Streets. Berkeley: University of California Press. Available at: https://www.amazon.com/Livable-StreetsDonald-Appleyard/dp/0520047699

Gehl, Jan. (1987). Life between Buildings: Using Public Space. New York: Van nor strand Reinhold. https://islandpress.org/books/lifebetween-buildings

Fruin, J., (1971). Pedestrian Planning and Design, NewYork: Metropolitan Association of Urban Designers and Environmental Planners. https://trove.nla.gov.au/work/1 4893042?a\&v ersionld $=25268257$

Iranmanesh, N.(2008). Pedestrianisation a great necessity in urban designing to create a sustainable city in developing countries, 44th ISOCARP Congress. http://www.isocarp.net/Data/case_studies/l 130.pdf

John Pucher and Lewis Dijkstra. (2000). Making Walking and Cycling Safer: Lessons from Europe. Transportation Quarterly, Vol. 54, and No. $3 . \quad$ http://www.alanparkerpest.org/Publications20002004files/ATRFpaper AP01.pdf

John Pucher and Lewis Dijkstra. (2003). Promoting Safe Walking and Biking to Improve Public Health: Lessons From The Netherlands And Germany. American Journal of Public Health, Vol. 93, No. 9, pp. 1509-1516. https://doi.org/10.2105/aiph.93.9.1509

Simpson, B, J. (1988); City Center Planning and Transport. England, Van strand Vein bold. https://trid.trb.org/view/291249

Refaat, H., Kafafy,N.(2014). Approaches and Lessons for enhancing walkability in cities: a
Landscape Conceptual Solution for Talaat Harb Street, Cairo. International Journal of Education and Research, 2 (6). 301-322. http://www.ijern.com/journal/June2014/24.pdf

Syed Sobri Zubir, Wan Azhar Sulaiman. (2004). Initiatives and Intervention in Promoting Pedestrianization in the Historic City of Melaka, Malaysia. The Fifth International Conference on Walking in the 21st Century Copenhagen, Denmark.

https://www.researchgate.net/publication/24 2213685 Initiatives and intervention_in_prom oting pedestrianization in the historic city of Melaka_Malaysia

MARC .(1998). Creating Walkable Communities: A guide for local governments, Planning

Commissioners Journal, Available at: www.bikewalk.org/pdfs/ncbwpubwalkablec omm.pdf (December 18th, 2015).

Longo,G, Brambilla,R.(2004). Pedestrian-zones: a design guide, time-saver standards for urban design. Donald Watson, Alan Plattus. https://www.accessengineeringlibrary.com/b rowse/time-saver-standards-for-urban-design

Gerrard B., Still B. and Jopson A. (2001). The impact of road pricing and workplace parking levies on the urban economy: results from a survey of business attitudes. Environment and Planning A, 33(1), 1985-2002. https://doi.org/10.1068/a3412

Grant J, Tolley R, Flannigan N. (2005). Encouraging and Increasing Walking: A policy document for the City of Yarra, City of Yarra. Yarra press. https://www.google.com/urle sa=t\&rct=j\&q=\& esrc $=s \&$ source $=$ web \&cd $=1 \& c a d=r j a \& v a c t=8$ \&ved=2ahUKEwidseiMtMLfAhXFLIAKHbAhDOw QFjAAegQICRAC\&url=https\%3A\%2F\%2Fwww. yarracity.vic.gov.au\%2F-

\%2Fmedia\%2Ffiles\%2Fthe-area\%2Fgettingaround\%2Fencouraging-and-increasingwalking-strategy-

2005.pdf\&usg=AO $\vee$ Vaw319ZtxdraRT1 JOwoyla ICD

Risser, R. and Chaloupka, C. (2010). Need. Paper for PQN Working Group 4, August 2010. In: PQN Final Report - part B.5 Policy process. Wal k21, Cheltenham.

New Zealand Transport Agency. (2009) .pedestrian planning and design guide [PDF] file, Available at: https://www.nzta.govt.nz/resources/pedestria n-planning-guide/ 